\title{
Effectiveness of Messenger Plants (Peperomia Pellucida L.) and Tai Chi Exercise as Modality Therapy for Elderly with Hyperuricemia: A Literature review
}

\author{
Lutfian Lutfian ${ }^{1 *}$, Nila Uli Saadah², Nur Rohmawati ${ }^{3}$
}

1,2,3Nursing Science, Faculty of Nursing, University of Jember, Indonesia; lutfian.ardianysah@aiesec.net (Corresponding Author)

\begin{tabular}{l}
\hline Article Info: \\
\hline Submitted: \\
14-10-2021 \\
Revised: \\
27-12-2021 \\
Accepted: \\
29-12-2021
\end{tabular}

DOI:

https://doi.org/10.53713/nhs.v1i3.80

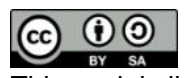

This work is licensed

under CC BY-SA License.

\begin{abstract}
Hyperuricemia correlated with an increase in monosodium urate crystals, which was a precipitating factor for gout arthritis. In Indonesia, this disease was more common in individuals over 34 years of age. The elderly who had gout can be associated with metabolic syndrome and increase the risk of cardiovascular disease. Pharmacological therapy of gout, such as allopurinol, had a greater potential to cause side effects in patients. This article aimed to determine the effectiveness of Peperomia pellucida and Tai Chi exercise to overcome hyperuricemia in elderly. The writing method used was a literature review. Articles were obtained through search sites: Google Scholar, Science-Direct, and NCBI, and the criteria used were Indonesian and English with a range of publication years 2014-2020. Eight main journals were used as references; from these journals, it was concluded that Peperomia pellucida could inhibit the formation of uric acid with xanthine oxidase activity through its quercetin-type flavonoid content in elderly, while Tai Chi exercise could increase joint flexibility and blood circulation in patients with gout. Therefore, it is hoped that the nurse can consider this modality therapy to be given to elderly with hyperuricemia. So, elderly with hyperuricemia can control their uric acid levels by implementing this combination therapy.
\end{abstract}

Keywords: gout; Peperomia Pellucida; Tai Chi

\section{INTRODUCTION}

Gout is a degenerative disease caused by the build-up of monosodium urate crystals in the body, especially in the joint area. A person is said to have gouty arthritis if the uric acid level in the blood is above normal limits (hyperuricemia), and the results of microscopic examination of joint fluid reveal monosodium urate crystals. This build-up of crystals can occur anywhere but is most common in the joints. Crystal deposition that occurs repeatedly will cause inflammation (Susianti et al., 2015). The typical clinical manifestation of gouty arthritis is joint enlargement which reduces joint mobility. This disease can affect more than one joint for a longer duration. Hyperuricemia in the elderly is associated with metabolic syndrome and increases the risk of comorbid diseases such as cardiovascular disease, and it is related to the enzyme xanthine oxidase and endothelial damage to blood vessels (Puspasari et al., 2017).

Patients with gout in the world continued to experience a two-fold increase between 1990-2010. The prevalence of hyperuricemia and gout in Asia in the last decade has reached $13 \%-25 \%$. It is estimated that gout occurs in 840 people out of every 100,000 people. In Indonesia, gout at the age of under 34 years is $32 \%$, and age above 34 is $68 \%$ (Hastuti et al., 2018). According to the World Health Organization (WHO), 24\% of gout sufferers in Indonesia go to doctors or other health workers, while $71 \%$ tend only to take over-the-counter pain relievers. Gout arthritis in Indonesia occupies the second position as a joint disease after osteoporosis (Jaliana et al., 2018).

Recommendations for gout management are pharmacological therapy and management of diet and lifestyle patterns. The recommended diet to reduce uric acid levels is to avoid consuming foods that contain lots of purines, such as organ meats and foods or fruit juices that contain high-fructose corn syrup (Harding, 2016). Pharmacological therapy such as allopurinol can cause more significant side effects than non-pharmacological therapy using herbal plants and physical exercise. In addition, non-pharmacological therapies tend to be in demand because they are relatively cheap and easy to find. However, not much is known about its benefits as a therapy for hyperuricemia.

Suruhan plants (Peperomia pellucida L.) have been used in traditional medicine for thousands of years to treat various diseases, such as gout (Prihastuti et al., 2017). Several studies have shown that Peperomia Pellucida has analgesic, anti-inflammatory, antipyretic, antioxidant, antihyperglycemic, anti-hyperuricemic, cytotoxic, antimicrobial, 
lipase inhibitor, and anti-osteoporosis effects (Farida et al. 2016). In addition, Peperomia Pellucida contains many alkaloids, tannins, saponins, quinines, and flavonoids that can be used to treat gout and skin inflammation. The optimal level of flavonoid in Peperomia Pellucida extract to inhibit xanthine oxidase activity is $300 \mathrm{gr}$. (Kartika et al., 2016). Based on Mutee's research (2010), the dose used is $1000 \mathrm{mg} / \mathrm{kg}$ body weight per day orally in male rats with oedema in the hind legs. The results show that herbal messengers can reduce uric acid levels not much different from allopurinol as a uric acid synthesis drug in mice (Bakar, A et al., 2018).

In addition to consuming ordered herbal plants, gout sufferers can also do Tai Chi Gymnastics. Tai Chi is an exercise regimen rooted in eastern philosophy and Chinese medicine (Holly Black 2015). This gymnastics is an exercise that combines physical movements, breathing, feelings, and thoughts in a single unit that aims to produce inner peace that has physical and psychological therapeutic value (Blake and Hawley, 2016). Thus, the supply of food and oxygen in the muscle tissue becomes better so that muscle flexibility increases. In addition, according to Komang (2017), tai chi exercise interventions can reduce joint pain in the elderly with hyperuricemia, rheumatism, and other joint pain (Kisner, 2014, Komang 2017).

Based on the above phenomenon, the authors are interested in conducting a literature review that aims to determine the Peperomia pellucida and tai chi exercise as therapy in older adults with gout by minimizing the side effects of therapy. Furthermore, it is hoped that this study can provide an overview of alternative therapies for nurse and the broader community in utilizing messenger plants that are very easy to get in the tropical environment of Indonesia and doing tai chi exercises.

\section{METHOD}

The method used in writing this article is a literature review. The literature used is articles obtained from electronic media obtained from Google Scholar, Science Direct, and NCBI through "Peperomia Pellucida and Gout", "Tai Chi Exercise and Gout", and "Peperomia Pellucida, Tai Chi Exercise and Gout". The criteria used in the search for articles were articles in Indonesian and English, published in 2015-2020, and articles reviewing the effectiveness of Peperomia pellucida and tai chi exercises for reducing hyperuricemia levels or related to joint disease, which has characteristics similar to gout. The literature collected according to the criteria will be analyzed and synthesized by categorizing it into problem analysis and potential problem solving so that an idea emerges based on scientific evidence and supported by previous research. The guidelines in writing this literature review use the PRISMA (Preferred Reporting Items for Systematic Reviews and Meta-analyses) method. To assess the feasibility of articles to be included in this study, the authors use the Critical Appraisal Skills Program (CASP).

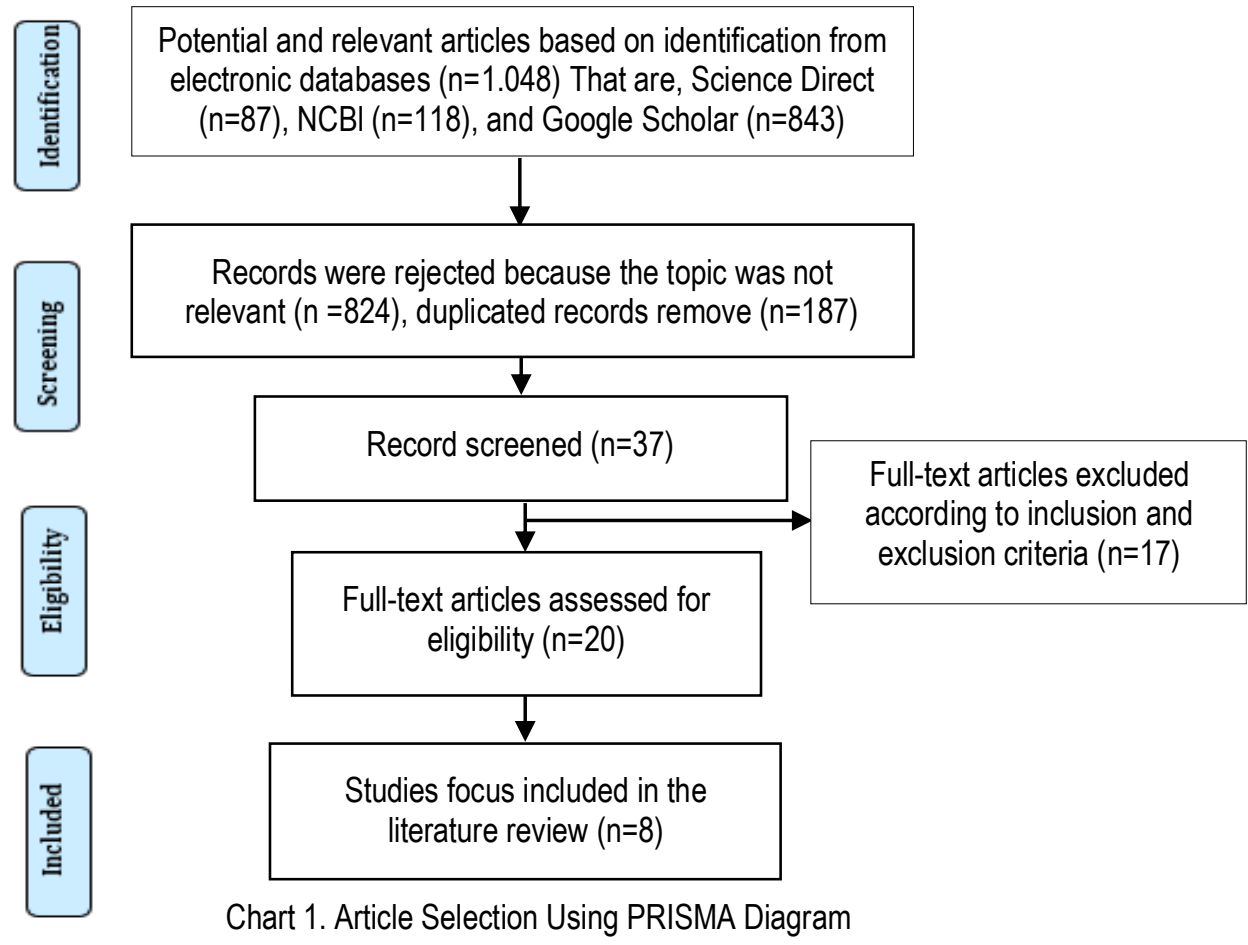


RESULT

Table 1. Journal analysis of 8 main articles included in this study

\begin{tabular}{|c|c|c|c|c|}
\hline Author & Year & Title of Articles & Method & Result \& Discussion \\
\hline $\begin{array}{c}\text { Asiyah } \\
\text { Dwiyaningsih }\end{array}$ & 2017 & $\begin{array}{l}\text { The Effect of } \\
\text { Ergonomic } \\
\text { Gymnastics and Tai } \\
\text { Chi Exercises on } \\
\text { Reducing Uric Acid } \\
\text { Levels in the Elderly }\end{array}$ & $\begin{array}{l}\text { Quasi- } \\
\text { experiment } \\
\text { with pre-test } \\
\text { and post-test } \\
\text { two group } \\
\text { design }\end{array}$ & $\begin{array}{l}\text { Based on the results of research } \\
\text { from } 60 \text { elderly respondents, it was } \\
\text { found that there was an effect of } \\
\text { decreasing uric acid levels before } \\
\text { and after giving Tai Chi exercises }\end{array}$ \\
\hline Riska Yunda B & 2018 & $\begin{array}{l}\text { The effect of Tai Chi } \\
\text { exercise on joint } \\
\text { pain and joint } \\
\text { flexibility in the } \\
\text { elderly at the Elderly } \\
\text { Posyandu }\end{array}$ & $\begin{array}{l}\text { pre- } \\
\text { eksprimen } \\
\text { with One } \\
\text { Group Pretest } \\
\text { Posttes } \\
\text { design }\end{array}$ & $\begin{array}{l}\text { After the six Tai Chi interventions, } \\
\text { the elderly experienced a decrease } \\
\text { in the level of moderate joint pain } \\
\text { from the number of respondents } 24 \\
\text { to } 8 \text { respondents. This study } \\
\text { showed a significant difference } \\
\text { after and before the intervention. }\end{array}$ \\
\hline $\begin{array}{l}\text { Komang Tri Adi } \\
\text { Suparwati, } \\
\text { Made Muliarta, } \\
\text { and } \\
\text { Muhammad } \\
\text { Irfan }\end{array}$ & 2017 & $\begin{array}{l}\text { Tai Chi Gymnastics } \\
\text { Is More Effective In } \\
\text { Increasing Flexibility } \\
\text { And Balance Than } \\
\text { Elderly Fitness } \\
\text { Gymnastics In The } \\
\text { Elderly In Denpasar } \\
\text { City }\end{array}$ & $\begin{array}{l}\text { Quasi- } \\
\text { experiment } \\
\text { with pre-test } \\
\text { and post-test } \\
\text { two group } \\
\text { design }\end{array}$ & $\begin{array}{l}\text { The results showed that there were } \\
\text { differences in the mean flexibility } \\
\text { and balance between the two } \\
\text { groups (Group 1 Tai Chi and other } \\
\text { fitness exercises) using the } \\
\text { independent T-test, which showed } \\
\text { a significant difference with the } \\
\text { average flexibility value of } 3.15 \mathrm{~cm} \\
\text { and }-3.15 / \mathrm{sec}\end{array}$ \\
\hline
\end{tabular}

\begin{tabular}{|c|c|c|c|c|c|}
\hline $\begin{array}{l}\text { Suci Indah P, } \\
\text { Diyan Indriyani } \\
\text { and Yeni } \\
\text { Suryaningsih }\end{array}$ & 2015 & $\begin{array}{l}\text { The Effect of Taichi } \\
\text { Exercise on Joint } \\
\text { Pain in the Elderly } \\
\text { at Nursing Home } \\
\text { Bondowoso }\end{array}$ & $\begin{array}{l}\text { Pra- } \\
\text { Eksperimental } \\
\text { with one- } \\
\text { group pretest } \\
\text { and posttest } \\
\text { design }\end{array}$ & $\begin{array}{l}\text { After the Tai Chi exercise } \\
\text { intervention in the elderly, the } \\
\text { results showed a difference in the } \\
\text { pain value of } 4.5758 \text { and after } \\
\text { being given gymnastics } \\
\text { tai chi } 1.1818\end{array}$ & $\begin{array}{l}\text { This research is } \\
\text { recommended to health } \\
\text { agencies to provide tai } \\
\text { chi exercises regularly, } \\
\text { especially at the } \\
\text { posyandu for the elderly. }\end{array}$ \\
\hline $\begin{array}{c}\text { Víctor Manuel } \\
\text { Mendozanúñez } \\
\text { Taide laurita } \\
\text { Arista-Ugalde, } \\
\text { Juana rosado- } \\
\text { Pérez, Mirna } \\
\text { ruiz-ramos, and } \\
\text { edelmiro } \\
\text { santiago-Osorio }\end{array}$ & 2018 & $\begin{array}{l}\text { hypoglycemic and } \\
\text { antioxidant effect of } \\
\text { Tai chi exercise } \\
\text { training in older } \\
\text { adults with } \\
\text { metabolic syndrome }\end{array}$ & $\begin{array}{l}\text { Quasi- } \\
\text { experiment } \\
\text { with pre-test } \\
\text { and post-test } \\
\text { two group } \\
\text { design }\end{array}$ & $\begin{array}{l}\text { A very statistically significant } \\
\text { decrease in the concentration of } \\
\text { HbA1c was observed in the Tai Chi } \\
\text { exercise group compared to the } \\
\text { control group, and the intervention } \\
\text { group also showed a statistically } \\
\text { significant increase in TAS and a } \\
\text { decrease in oxidative scores. }\end{array}$ & $\begin{array}{l}\text { This study found that the } \\
\text { intervention of Tai Chi } \\
\text { exercise in the elderly } \\
\text { has antioxidant and } \\
\text { hypoglycemic effects. } \\
\text { Therefore, it can be } \\
\text { recommended to make } \\
\text { Tai Chi exercise for the } \\
\text { elderly with gout. }\end{array}$ \\
\hline $\begin{array}{l}\text { Yunahara } \\
\text { Farida and } \\
\text { Rifaldi Agustian } \\
\text { Firmansyah }\end{array}$ & 2016 & $\begin{array}{l}\text { Xanthine Oxidase } \\
\text { Inhibitory Activity } \\
\text { Ethanol and Water } \\
\text { Extract from Herbs } \\
\text { (Peperomia } \\
\text { pellucida L.) }\end{array}$ & $\begin{array}{l}\text { Experimental } \\
\text { studies with } \\
\text { comparison }\end{array}$ & $\begin{array}{l}\text { messenger plant (Peperomia } \\
\text { pellucida L.) is a plant that has } \\
\text { activity in inhibiting xanthine } \\
\text { oxidase. The test results showed } \\
\text { that the thick extract of the ordered } \\
\text { herbs in ethanol solvent and water } \\
\text { solvent had a total flavonoid } \\
\text { content of } 4.23 \% \text { and IC50 } 40.79 \\
\text { bpj, and the thick extract of ordered } \\
\text { herbs in water solvent had a } \\
\text { flavonoid content of } 1.43 \% \text { and } \\
\text { IC50 } 43.11 \text { bpj. Ethanol extract and } \\
\text { herbal water have an inhibitory } \\
\text { effect on xanthine oxidase. }\end{array}$ & $\begin{array}{l}\text { Peperomia pellucida } \\
\text { contains a class of } \\
\text { flavonoid compounds, } \\
\text { alkaloids, saponins, } \\
\text { quinones and steroids. } \\
\text { The ethanol extract of } \\
\text { the messenger herbs } \\
\text { had a better xanthine } \\
\text { oxidase inhibitory activity } \\
\text { (IC50 } 40.79 \text { bpj) than the } \\
\text { aqueous extract of the } \\
\text { herbal extracts (IC50 } \\
43.11 \text { bpj). }\end{array}$ \\
\hline
\end{tabular}


Table 1. Journal analysis of 8 main articles included in this study (Cont.)

\begin{tabular}{|c|c|c|c|c|c|}
\hline Author & Year & Title of Articles & Method & Result \& Discussion & Conclusion \\
\hline Ema P. Yunita & 2018 & $\begin{array}{l}\text { Relationship } \\
\text { Between Obesity, } \\
\text { High Purine } \\
\text { Consumption, and } \\
\text { Treatment of Gout } \\
\text { With Allopurinol. }\end{array}$ & $\begin{array}{l}\text { Quasi- } \\
\text { experiment } \\
\text { with pre-test } \\
\text { and post-test } \\
\text { design }\end{array}$ & $\begin{array}{l}\text { The study's findings revealed that } \\
\text { individuals who consumed high- } \\
\text { purine foods without restriction and } \\
\text { took aspirin, although taking the } \\
\text { medicine allopurinol, had } \\
\text { uncontrolled uric acid levels. }\end{array}$ & $\begin{array}{l}\text { Although the patient took } \\
\text { allopurinol, this study } \\
\text { found no link between } \\
\text { obesity, high purine } \\
\text { consumption, and } \\
\text { medicine consumption } \\
\text { that affects uric acid } \\
\text { levels. }\end{array}$ \\
\hline $\begin{array}{c}\text { Angelina Ajeng } \\
\text { Prihastuti, Sumi } \\
\text { Wijaya, Lanny } \\
\text { Hartanti }\end{array}$ & 2017 & $\begin{array}{l}\text { Xanthine Oxidase } \\
\text { Inhibitor Activity } \\
\text { Test from The } \\
\text { Fraction of } \\
\text { Peperomia pellucida } \\
\text { Ethanol Extract }\end{array}$ & Experimental & $\begin{array}{l}\text { The result showed that ethyl } \\
\text { acetate-ethanol fraction potentially } \\
\text { inhibited xanthine oxidase with an } \\
\text { IC50 value of } 5.00 \pm 0.06 \mathrm{ppm} \text {, } \\
\text { while ethanolic extract of } \\
\text { Peperomia pellucida (L.) Kunth } \\
\text { herb and allopurinol have IC50 } \\
\text { values } 0.33 \pm 0.07 \mathrm{ppm} \text { and } 0.84 \pm \\
0.02 \mathrm{ppm} \text {, respectively. }\end{array}$ & $\begin{array}{l}\text { The ethyl acetate-ethanol } \\
\text { fraction of the ethanol } \\
\text { extract of the messenger } \\
\text { herb (Peperomia } \\
\text { pellucida I) had an } \\
\text { inhibitory effect on the } \\
\text { xanthine oxidase enzyme } \\
\text { with an IC50 value of } \\
5.00+0.06 \text { ppm. Thus, } \\
\text { the ethyl acetate-ethanol } \\
\text { fraction of ordered herbs } \\
\text { containing flavonoids has } \\
\text { a potency of } 5 \text { times less } \\
\text { than allopurinol and } 15 \\
\text { times less than its extra } \\
\text { ethanol. }\end{array}$ \\
\hline
\end{tabular}

Based on those who have met the inclusion criteria, an increase in results related to an increase in the range of motion of the elderly, a decrease in pain, flexibility of researchers, the balance of journals that took part in tai chi exercises was obtained. In addition, an ethanolic extract was discovered based on the components in the Peperomia pellucida $L$. that serves as an inhibitor of xanthine oxidase. This enzyme functions as a catalyst in the oxidation of hypoxanthine to xanthine and then to uric acid.

\section{DISCUSSION}

\section{Risk of Gout Arthritis and Hyperuricemia}

Hyperuricemia is caused by high uric acid levels in the body due to excessive uric acid synthesis and decreased excretion of uric acid in the distal tubule of the kidney. Hyperuricemia accompanied by synovial fluid or soft tissue saturation can increase the risk of formation of sharp monosodium urate crystals and trigger inflammation. Monocytes and macrophages will eliminate crystals through phagocytosis accompanied by the release of inflammatory mediators into the surrounding area and trigger inflammation and tissue damage (Muqorrobin, 2017). Diet and the breakdown of ribonucleic acid from cells produce purines as the end product of metabolism. Through the normal pathway, the purines will be metabolized by hypoxanthine and converted to xanthine. Xanthine through the enzyme xanthine oxidase will be overhauled into uric acid. The kidneys will excrete uric acid through urine-a mechanism of inhibition of uric acid formation through xanthine oxidase inhibitors.

\section{Messenger plant (Peperomia pellucida) in reducing the amount of uric acid}

This plant (Peperomia pellucida I) has been used in traditional medicine for thousands of years to treat various diseases. Chinese betel contains many alkaloids, tannins, saponins, quinine, and flavonoids, which can treat acne, gout, skin inflammation, or ulcers. Herbs have properties as an analgesic and antipyretic, anti-inflammatory, antioxidant, antimicrobial and anticancer, antihyperglycemic, and antihyperuricemia (Farida et al., 2016). In addition, it has a spicy and cool aroma and has anti-fungal properties. Orders can be consumed directly as fresh vegetables, used as a concoction by drinking boiled water or grinding, and then affixed to the affected area.

Based on Mutee (2010) research, the dose that can be used is $1000 \mathrm{mg} / \mathrm{kg}$ body weight per day orally in male rats with oedema in the hind legs. The results show that herbal messengers can reduce uric acid levels not much different from allopurinol as a uric acid synthesis drug in mice (Bakar, A et al., 2018). Several studies have shown many 
pharmacological effects contained in peperomia pellucida, including analgesic, anti-inflammatory, antipyretic, antioxidant, antihyperglycemic, antihyperuricemia, cytotoxic, antimicrobial, cell anisikling, a lipase inhibitor, fibrinolytic, thrombolytic, antidiarrheal, and antiosteoporosis. The optimal level of flavonoids in the Chinese extract to inhibit xanthine oxidase activity is $300 \mathrm{~g}$. (Kartika et al., 2016).

Common flavonoid compounds in inhibiting xanthine oxidase are apigenin, luteolin, camphorol, quercetin and myricetin. The content of flavonoids in the herbs has the effect of lowering uric acid levels by inhibiting the activity of the enzyme xanthine oxidase on purine bases so that the production of uric acid can be reduced. The content of flavonoids can inhibit the activity of the xanthine oxidase enzyme through competitive inhibition. Quercetin type flavonoid has a hydroxyl group that is competitive with xanthine (substrate). Therefore, flavonoids (quercetin) can react more with the xanthine oxidase enzyme so that the inhibitory effect of uric acid formation can last as long as the flavonoids are still in the plasma. The optimal level of flavonoids in the extract of the Chinese order to inhibit the activity of xanthine oxidase is $200 \mathrm{gr}$.

Yunahira (2016) explained that the inhibitory effect of xanthine oxidase inhibitory water extract of $50 \mathrm{~mL}$ china was $51.77 \%$ with IC50, or the concentration that could inhibit xanthine oxidase enzyme activity $50 \%$ of the Chinese extract was $43.11 \%$. Therefore, the IC50 of the alkaloid extract was lower than that of the ethanolic extract, indicating that the alkaloidal extract was more active than the ethanolic extract. This follows the statement that active alkaloid compounds inhibit the xanthine oxidase enzyme (Farida and Firmansyah, 2016). This is supported by the results of research conducted by Imbar et al. (2019), namely the ethanol extract of the host plant can have the effect of reducing uric acid levels with a dose of $200 \mathrm{mg}$ of the ethanol extract of the messenger plant, which is the optimum dose in lowering uric acid levels. Therefore, the ethanol extract of the messenger plant can be recommended as an alternative medicine to reduce uric acid. The ability of the ethanol extract of the messenger plant to reduce uric acid levels in the blood is thought to be caused by the flavonoid compounds contained in the plant extract (Imbar et al., 2019).

In addition, research by Kartika et al. (2016) showed that the anti-inflammatory effect of the herbal plant was able to inhibit oedema at a dose of $400 \mathrm{mg} / \mathrm{kg}$ BW close to indomethacin $10 \mathrm{mg} / \mathrm{kg} \mathrm{BW}$. Oral administration of ordered herbal plant extracts at a dose of $1500-2500 \mathrm{mg} / \mathrm{kg}$ WB significantly affects inflammation. The antihyperuricemia effect of the suruhan herb showed that the ethanol extract at a dose of $50 \mathrm{mg} / \mathrm{kg}$ could reduce uric acid levels by $24.35 \%$, while a dose of $200 \mathrm{mg} / \mathrm{kg}$ reduced uric acid levels by $31.52 \%$, and a dose of $100 \mathrm{mg} / \mathrm{kg}$ reduced uric acid levels. uric acid $32.20 \%$ (Kartika, et al., 2016).

\section{Tai Chi Exercise}

\section{The advantages of Tai Chi on Fitness, Flexibility and Joint Pain}

Tai Chi gymnastics consists of functional movements that are carried out daily, such as walking, standing, squatting, sitting to standing, and going up and down stairs which are still not found in fitness gymnastics and other physical exercises that are often done by the elderly such as yoga, swimming, cycling. Relaxing, ergonomic exercise. Research conducted by Lam and Horstman in 2013 showed that Tai Chi exercise interventions with several modifications could improve muscle strength, balance, flexibility or flexibility, and increase pain threshold and improve the overall quality of life (Suci, 2017).

Pharmacological therapy of hyperuricemia has a greater potential to cause side effects than non-pharmacological therapy using herbal plants and physical exercise. In addition, non-pharmacological therapies tend to be in demand because they are relatively cheap and easy to find. China's messenger plants are not widely known for their benefits as a therapy for hyperuricemia. The principle of giving Chinese tea is that individuals are encouraged to fast for 2 hours before drinking the tea. This therapy can be continued until uric acid levels return to normal. Based on several studies, giving this tea can be done for 14 days to achieve optimal results.

The target of this research intervention, especially Tai Chi exercise, is the elderly aged 60 years and over who are advised to do light exercise that is not too burdensome to the bones (Suci, 2015). In Tai Chi gymnastics, there are dynamic active stretching movements, semi squats, closed-chain-kinetic, and core stability exercises from the beginning of the exercise to the end, which is useful for increasing flexibility and balance in the elderly due to changes in muscle morphology, sensory systems and the occurrence of cartilage protein depletion from elderly joints. Semi squat movement with closed-chain-kinetic will activate the quadriceps muscle group, lumbar vertebrae muscles and pelvic floor muscles. Performing semi-squat movements with closed-chain-kinetic will stimulate the quadriceps muscle group, especially the vastus medial oblique and vastus lateral (Kisner, 2014, Komang 2017). Closed-Chain-Kinetic provides a large proprioceptive and kinesthetic stimulus through the resulting joint approximation. Multiple contractions accompanied by weight-bearing elements (axial loading) during the closed-kinetic-chain process cause joint approximation; this stimulates mechanoreceptors in muscles and receptors around the joint to increase sensory input in the movement control process. Closed-kinetic-chain involves a strengthening component between the agonist and 
antagonist knee muscles simultaneously related to the physiological movements of the lower limbs; besides that, eccentric muscle work occurs during closed-kinetic-chain administration, resulting in greater tension in the muscles so that it further increases the ability functional (Komang, 2017).

Then the Core Stability movement is the coactivation of the inner muscles of the lower trunk to control weight transfer and stepping during the walking process. Tai Chi has core stability exercises that develop the work of the dynamic muscular corset muscles. Coordinated and concurrent contractions of these muscles will provide calendar rigidity to support the trunk, resulting in reduced intradiscal pressure. In addition, they will reduce the workload of the lumbar muscles so that the tissue is not easily injured; abnormal lumbar muscle tension will be reduced so that there is an improvement in the muscle pump, which results in increased blood circulation in the back muscle tissue (Komang, 2017).

The supply of food and oxygen in muscle tissue becomes better, so that muscle flexibility increases. The activation of the core muscles that function as spinal stabilizing muscles will relax the global muscles that were previously spasming, thereby obtaining good vertebral stability and the spine's position in a state of functional activity. Reduced intradiscal pressure will make it easier to perform functional activities. It can be concluded that the tai chi exercises intervention affects joint pain in the elderly with hyperuricemia, rheumatism and other joint pain (Kisner, 2014, Komang 2017).

Older adults with gout or at risk for hyperuricemia will be given Tai Chi exercise therapy in the morning around 06.00-07.00 WIB (Riska, 2018, Aisyah, 2017, Suci, 2015) and combined with herbal therapy Peperomia pellucida for approximately 15 days or when the elderly uric acid levels are normal. The techniques used in Tai Chi exercises include dynamic active stretching movements, semi squats, closed-chain-kinetic, and core stability exercises that function to decrease muscle tension, reduce joint pain, and increase muscle flexibility, which is carried out for approximately 20 minutes. -30 minutes every day for 15 days (Riska, 2018). The technique to consume tea made from peperomia pellucida drunk tea water boiled with hot water at a temperature of around $100 \mathrm{C}$ is as much as one in a day with the dose in a teabag that has been measured (Sagita, 2014). The result expected from the combination of Tai Chi exercise therapy with tea orders is to help the elderly who experience gout to easily accelerate the decrease in uric acid levels and as a modality and complementary therapy to reduce the side effects of pharmacological drugs.

\section{CONCLUSION}

From the eight main journals analyzed by the authors, it was concluded that the messenger herbal plant (Peperomia pellucida I), based on several studies in vitro and in vivo, could inhibit xanthine oxidase through a mechanism that occurs due to the flavonoid content in its $1000 \mathrm{mg} / \mathrm{kg}$ body weight. In addition, tai chi exercise can be used for muscle strength, balance, flexibility or flexibility, and can lower the pain threshold. It is hoped that the nurse can consider the effectiveness of this combination therapy to be implemented to the elderly with hyperuricemia. We believe that consuming peperomia pellucida and doing thai chi exercise can control the elderly uric acid level. This therapy is an appropriate and complementary approach which is easly carried out by older adults with gout, because this therapy is simple and consists of slow movements with lower joint impacts and loading, safe, and low-cost exercise.

\section{ACKNOWLEDGEMENT}

Thanks for support from the Faculty of Nursing, University of Jember so this literature review can be carried out successfully. We also extend our thanks to all the authors of the references used in this literature review.

\section{REFERENCES}

Bakar, A, F. I., Bakar, A, M. F., Rahmat, A., Abdullah, N., Sabran, A. F., and Endrini, S. (2018). Anti-gout Potential of Malaysian Medicinal Plants. Frontiers In Pharmacology: 1-14

Asiyah, D. 2017. Pengaruh Senam Ergonomis dan Senam Tai Chi Terhadap Penurunan Kadar Asam Urat Lansia. Yogyakarta : Universitas Aisyiah

Astanti, R. W. (2018). Pengaruh senam Tai Chi terhadap Nyeri Persendian dan Fleksibelitas Sendi pada Lansia di Posyandu Lansia Desa Kiniteng Kecamatan Gineng Kabupaten Ngawi. Ngawi: Stikes Bakti Mulia

Blake, H., and Hawley, H. (2012). Effects of Tai Chi Exercise on Physical and Psychological Health of Older People. 19-27

Farida, Y. and Firmansyah, R. A. (2016). Aktivitas Penghambatan Xanthine Oxidase Ekstrak Etanol and Air Rebusan Herba Suruhan (Peperomia pellucida L.). Prosiding Seminar Nasional Tumbuhan Obat Indonesia. 482-487

Harding, M. (2016) 'An update on Gout on Primary Care Provider', The Nurse Practitioner, 41(4), pp. 14-21. DOI: 10.1097/01.NPR.0000481510.32360.fa 
Jaliana, Suhadi, and Sety, L. O. M. (2018). The Related Factors With The Incidence Of Uric Acid Among Patient Age 20-44 Years Old In Bahteramas General Hospital Of Southeast Sulawesi Province In 2017. Jimkesmas. 3(2): 2-13

Johnson, J. Y. (2010) Handbook for Brunner \& Suddarth Textbook of Medical-Surgical Nursing. 12th editions. Edited by H. Surrena. Philadelphia: Lippincott Williams \& Wilkins

Kisner, C., Colby, AL., (2014). Therapeutic Exercise. $6^{\text {th }}$ ed. Philadelphia: F. Davis Company

Komang, T.A.S, M.Muliarta, and Irfan. (2017). Senam Tai Chi Lebih Efektif Meningkatkan Fleksibilitas And Keseimbangan Daripada Senam Bugar Lansia Pada Lansia Di Kota Denpasar. Sport and Fitness Journal. 5(1),92-93

Muqorrobin, A. (2017). Efektivitas senam Tai Chi terhadap penurunan Kolestrol Total pada Lansia (1st ed.). Jombang: Stikes Insan Cedia Medika

Puspasari, K., Khomsan, A., and Anwar, F. (2017). Kadar Asam Urat Suku Serawai dan Suku Jawa di Kabupaten Kepahiang. Jurnal MKMI. 13(2), 152-156

Yunda, B. (2018). Pengaruh senam Tai Chi terhadap nyeri persednian dan fleksibelitas sendi pada lansia di Posyandu Lansia. Jombang : Stikes

Sagita, N. (2014). Pengaruh Suhu Dan Waktu Penyeduhan Teh Hijau (Camellia Sinensis) Serta Proses Pencernaan In Vitro Terhadap Aktivitas Inhibisi Lipase Bogor: IPB

Suci, I.P., D. Indriyani and Y. Suryaningsih. (2015). Pengaruh Senam Taichi Terhadap Nyeri Persendian Pada Lansia Di Upt PSTW Bondowoso. Jember : UMJ

Susianti, Kurniawan, B., Zuraida, R., and Mutiara, H. (2015). Pemeriksaan Kadar Asam Urat dan Penyuluhan tentang Penyakit Gout pada Masyarakat di Desa Kalisari Kecamatan Natar Kabupaten Lampung Selatan. JPM Ruwa Jurai. 1(1), 64-66

Sutanto. (2010). The Great Harmony on Tai Chi. Jakarta: Kompas

Víctor, M. M., T. Ugalde, J. Pérez.(2015). hypoglycemic and antioxidant effect of Tai chi exercise training in older adults with metabolic syndrome 